\title{
Selection of Trichoderma isolates for biological control of Sclerotinia minor and $S$. sclerotiorum in lettuce
}

\author{
Luciana Mecatti Elias ${ }^{1}$, Manuel Victor P. F. Domingues ${ }^{2}$, Karina Elaine de Moura², Ricardo Harakavaªnd Flávia \\ Rodrigues Alves Patricio².
}

\begin{abstract}
${ }^{1}$ Laboratório de Química Orgânica de Produtos Naturais, Departamento de Ciências Exatas, ESALQ/USP, Caixa Postal 09, CEP 13418-900, Piracicaba, SP, Brazil, ${ }^{2}$ Centro Experimental Central do Instituto Biológico, Instituto Biológico, Caixa Postal 70, CEP 13012-970, Campinas, SP, Brazil, ${ }^{3}$ Centro de Pesquisa e Desenvolvimento em Sanidade Vegetal, Instituto Biológico, Av. Cons. Rodrigues Alves, 1252, CEP 04014-002, São Paulo, SP, Brazil
\end{abstract}

Corresponding author: Flávia Rodrigues Alves Patrício (flavia@biologico.sp.gov.br)

Data de chegada: 27/11/2015. Aceito para publicação em: 16/02/2016.

$10.1590 / 0100-5405 / 2147$

\section{ABSTRACT}

Elias, L.M.; Domingues, M.V.P.F.; Moura, K.E.; Salomão, D.; Harakava, R.; Patricio, F.R.A. Selection of Trichoderma isolates for biological control of Sclerotinia minor and S. sclerotiorum in lettuce. Summa Phytopathologica, v.42, n.3, p.216-221, 2016.

Lettuce drop is one of the most important and difficult-to-control diseases affecting lettuce in Brazil and worldwide. This study was carried out to select Trichoderma isolates antagonistic to Sclerotinia minor and S. sclerotiorum, aiming to develop biological control for this pathosystem in Brazil. Thirty-one Trichoderma isolates were obtained with the use of baits and were tested under laboratory conditions for their ability to control S. minor and S. sclerotiorum in seedlings of lettuce cultivar Tainá cultured in Petri dishes containing water-agar medium. Subsequently, four isolates effective for control and showing high sporulation under laboratory conditions were evaluated in greenhouse in two experiments carried out with both pathogens in lettuce seedlings of the same cultivar. Twenty-two isolates showed ability to control S. minor and S. sclerotiorum in the in vitro experiments. The isolates tested under greenhouse conditions, identified as T. asperellum (IBLF 897, IBLF 904 and IBLF 914) and T. asperelloides (IBLF 908), reduced lettuce drop of seedlings caused by both pathogens but were more effective against $S$. minor. Biological control is a promising technology for the management of lettuce drop, especially because $S$. minor is the predominant species in infested lettuce fields in Brazil.

Keywords: lettuce drop, Lactuca sativa L., Trichoderma asperellum, Trichoderma asperelloides

\section{RESUMO}

Elias, L.M.; Domingues, M.V.P.F.; Moura, K.E.; Salomão, D.; Harakava, R.; Patricio, F.R.A. Seleção de isolados de Trichoderma para o controle biológico de Sclerotinia minor e S. sclerotiorum em alface. Summa Phytopathologica, v.42, n.3, p.216-221, 2016.

A murcha de esclerotínia é uma das doenças mais importantes e difíceis de controlar da cultura da alface no Brasil e em muitos países. Este estudo foi realizado para selecionar isolados de Trichoderma antagônicos a Sclerotinia minor e S. sclerotiorum visando a desenvolver o controle biológico para este patossitema no Brasil. Trinta e um isolados de Trichoderma foram obtidos pela técnica de isca e testados em condições de laboratório com relação à sua habilidade de controlar $S$. minor e $S$. sclerotiorum, em plântulas de alface da cultivar Tainá, dispostas em placas de Petri contendo ágar-água. Subsequentemente quatro isolados eficientes para o controle e com elevada esporulação em condições de laboratório foram avaliados em casa-de-vegetação, em dois experimentos com ambos os patógenos em plântulas de alface da mesma cultivar. Vinte e dois isolados demonstraram capacidade de controlar S.minor e S. sclerotiorum nos experimentos conduzidos in vitro. Em condições de casa-de-vegetação os isolados testados, identificados como T. asperellum (IBLF 897, IBLF 904 e IBLF 914) e T. asperelloides (IBLF 908), reduziram o tombamento das mudas de alface causado por ambos os patógenos, mas foram mais efetivos para S. minor. O controle biológico da murcha de esclerotínia é uma tecnologia promissora para o manejo da doença, especialmente porque $S$. minor é a espécie predominante nos campos de produção de alface infestados do Brasil.

Palavras-chave: podridão de esclerotínia, Lactuca sativa L., Trichoderma asperellum, Trichoderma asperelloides.

Lettuce production can be reduced by diseases such as lettuce drop, which is caused by Sclerotinia minor and S. sclerotiorum and is one of the most important diseases affecting lettuce in Brazil (19) and worldwide (20). A wide range of hosts, over 405 plant species, can be infected by S. sclerotiorum, while $S$. minor is reported to affect 94 plant species (22).

Although both pathogens are the causal agents of lettuce drop, they differ in some aspects. The sclerotia produced by S. minor are quite circular, with a diameter of 0.5 to $2.0 \mathrm{~mm}$, and germinate eruptively. In this species, carpogenic germination and apothecium production are extremely rare (23). S. minor infects the lower leaves of lettuce heads through germination of their sclerotia and can cause lettuce drop in two stages. In the first stage, which occurs right after thinning, only a small number of plants wilt and die. In the second stage, which begins as soon as the lettuce heads are formed and persists until immediately before harvest, a larger number of plants may be affected and collapse $(9,23)$. When cool and moist weather conditions prevail, $S$. minor forms a white mycelium with numerous small black sclerotia that can infect stems and leaves in contact with the soil, causing brown soft decay that can destroy the whole plant (23).

On the other hand, S. sclerotiorum produces fewer and larger sclerotia, very irregular in shape, which can measure from 2 to $20 \times 3$ to 
$7 \mathrm{~mm}$ and germinate carpogenically, producing one to several apothecia, which are important in the disease epidemic (23). Although similar weather conditions are favorable for infection by S. sclerotiorum, this species can infect through the germination of sclerotia or ascospores formed in the apothecia, which are quite frequent in this species. When the infection is caused by ascospores, it can occur on any part of the lettuce plants where the ascospores were deposited, and the disease can be very severe, with losses involving up to $70 \%$ of the lettuce heads (23).

The management of lettuce drop is complex, especially because of the differences in the epidemiology of this disease caused by the two Sclerotinia species. There is a correlation between the number of sclerotia produced by $S$. minor in the soil near the lettuce plants and the disease incidence in lettuce fields (17). In several lettuce-producing areas, this pathogen is more relevant because of its ability to produce a larger number of sclerotia. Although epidemics of lettuce drop caused by S. sclerotiorum can be more severe, it produces fewer sclerotia and apothecia, which occurs only after prolonged wet periods $(17,23)$. Fungicides such as iprodione, procymidone, boscalid and fluazinam $(14,19)$ are used to control lettuce drop caused by $S$. minor immediately after thinning, in stages containing 4 to 5 true leaves $(14,19)$, but repeated applications of fungicides may favor microbial populations that rapidly degrade fungicides in the soil, reducing the treatment efficiency $(14,22)$. Chemical control of $S$. sclerotiorum is usually more difficult because the ascospores can infect any part of the lettuce head; it is also more difficult to prevent once the apothecia is formed (17). Therefore, lettuce drop management is usually acquired by integrating fungicide applications with several other control methods such as deep plowing, roughing, crop rotation and subsurface-drip irrigation (22). Deep plowing of the soil may bury the sclerotia in deep soil layers, where they may be degraded by antagonists (22). Roughing of wilted plants may reduce the severity of the disease caused by $S$. minor, but it is considered a costly technique. Crop rotation with broccoli and subsequent incorporation of residues is used to reduce the severity of lettuce drop by producers in California (22), but lettuce producers in Brazil are resistant to crop rotation. Another technology used in California, sub-surface drip irrigation, may reduce lettuce drop (22), but it has not been extensively adopted in Brazil. Resistant varieties are very difficult to obtain and are not available at the moment (22). Biological control could be an interesting tool to be used integrated with other methods to promote lettuce drop management, but presently it has not been developed for this disease in Brazil.

In previous studies, antagonists were evaluated for the biological control of lettuce drop, showing diverse results. Under field conditions, Knudsen et al. (12) found that isolates of Trichoderma spp. added to the soil parasitized S. sclerotiorum sclerotia, reduced $100 \%$ infection and enhanced head weight. Rabeendran et al. (20) showed that isolates of $T$. hamatum or Coniotyrium minitans were effective in controlling $S$. minor under field conditions. On the other hand, Chitrampalam et al. (4), while testing commercial biological products formulated with $T$. harzianum, Gliocladium virens, C. minitans and Bacillus subtilis for lettuce drop management, observed that the product formulated with $C$. minitans was able to control $S$. sclerotiorum, but no biological product was able to control S. minor. In Brazil, Ethur et al. (6) isolated several fungi from the sclerotia of S. sclerotiorum, such as Aspergillus, Penicillium and Fusarium, but only the Trichoderma isolates demonstrated an ability to inhibit the mycelial growth of $S$. sclerotiorum.

Recently in Mexico, Ibarra-Medina et al. (10) obtained four Trichoderma isolates with the ability to parasitize sclerotia of $S$. minor and S. sclerotiorum. In a study carried out in Brazil with a similar pathosystem, Ethur et al. (7) observed that isolates of Trichoderma spp. reduced the damping-off of cucumber seedlings caused by $S$. sclerotiorum. On the other hand, Paula Júnior et al. (18) found that a commercial product formulated with Trichoderma was not effective for controlling $S$. sclerotiorum in a bean crop.

Antagonists of the genus Trichoderma are among the most frequently isolated soil fungi present in plants and roots, showing biocontrol properties, ability to colonize the rhizosphere and ability to improve plant health and stimulate plant growth (25). They are employed for the preparation of several commercial formulations to be used as biopesticides, biofertilizers, and soil amendments (25).

The present study was carried out to obtain isolates of Trichoderma antagonists to $S$. minor and $S$. sclerotiorum with the aim of developing the biological control of this disease in Brazil.

\section{MATERIALS AND METHODS}

\section{Isolates of $S$. minor, $S$. sclerotiorum and Trichoderma}

The isolates of $S$. minor and S. sclerotiorum were obtained from lettuce plants in the region of Mogi das Cruzes, São Paulo State, Brazil. Trichoderma isolates were obtained from soils collected at CEIB, Instituto Biológico, Campinas, São Paulo State, Brazil, using the methodology of baits prepared with wheat grains, adapted from Ghini and Kimati (8).

The wheat grains used as baits and inocula in the subsequent experiments were prepared by placing the previously moistened wheat grains in plastic bags autoclaved for one hour at $120^{\circ} \mathrm{C}$ on two consecutive days. Each plastic bag containing $400 \mathrm{~g}$ of wheat grains received 20 mycelial discs of $S$. minor or S. sclerotiorum previously grown for seven days in potato dextrose agar medium (PDA). The bags were kept in a laboratory at room temperature for 10 days, until they were completely colonized by the mycelium of the pathogens. Petri dishes containing the soil samples received 20 baits per plate and, after incubation for four to five days in the laboratory, they were observed under a stereoscopic microscope. When mycelium and conidia characteristic of Trichoderma were observed on the baits, they were transferred to Petri dishes containing PDA plus streptomycin $(0.2 \%)$. Whenever necessary, the colonies were transferred again to PDA until pure cultures of each isolate were obtained.

The isolates of Trichoderma were multiplied in rice grains previously sterilized $(200 \mathrm{~mL}$ of rice grains plus $100 \mathrm{~mL}$ of distilled water placed in plastic bags and autoclaved at $121^{\circ} \mathrm{C}$ for 60 minutes on two consecutive days). Twenty mycelial discs from the edge of colonies of the isolates of Trichoderma spp. were added to each bag and the bags were maintained for 10 days at room temperature, until they were covered with mycelial growth, showing abundant sporulation.

The Trichoderma isolates were selected under laboratory conditions and in two experiments conducted in a greenhouse.

\section{In vitro selection of Trichoderma isolates}

Thirty-one isolates of Trichoderma were evaluated in Petri dishes containing water-agar medium and lettuce seedlings. Suspensions of each Trichoderma isolate containing $10^{6}$ conidia per milliliter of sterile distilled water were prepared, and $0.5 \mathrm{~mL}$ of each suspension were added to the surface of $9 \mathrm{~cm}$-diameter Petri dishes containing water-agar medium. One wheat seed colonized with $S$. minor or S. sclerotiorum was placed in the center of each Petri dish; then, ten recently germinated seedlings of lettuce cultivar Tainá (lettuce seeds were maintained at $20{ }^{\circ} \mathrm{C}$ for 48 hours in Petri dishes containing two sheets of moistened filter paper) were evenly distributed near the border of each Petri dish 
which had previously received the wheat seed. Control treatments were prepared only with the pathogens and the lettuce seedlings and also with the lettuce seedlings without any microorganism. Petri dishes were kept in a BOD incubator, set at $25^{\circ} \mathrm{C}$ with a photoperiod of $12 \mathrm{~h} \mathrm{light}$ $/ 12 \mathrm{~h}$ dark. After six days, the seedlings of each plate were collected and their lengths were evaluated. The number of viable seedlings was also counted.

The 31 isolates of Trichoderma were evaluated in four experiments with both pathogens each. Ten isolates (IBLF 880, IBLF 881, IBLF 882, IBLF 883, IBLF 885, IBLF 886, IBLF 887, IBLF 888, IBLF 889 and IBLF 891) were tested in the first experiment, 10 (IBLF 884, IBLF 890, IBLF 892, IBLF 894, IBLF 895, IBLF 900, IBLF 901, IBLF 903, IBLF 904 and IBLF 906) in the second, six (IBLF 896, IBLF 897, IBLF 908, IBLF 910, IBLF 912 and IBLF 914) in the third, and five (IBLF 919, IBLF 923, IBLF 924, IBLF 926 and IBLF 931) in the fourth experiment. The isolates considered effective were the ones which enhanced the number and the size of lettuce seedlings.

\section{In vivo selection of Trichoderma isolates}

In the greenhouse experiments, four Trichoderma isolates IBLF 897, IBLF 904, IBLF 908 and IBL 914 were used because they were effective in controlling $S$. sclerotiorum and $S$. minor in the in vitro experiments and also because they showed rapid growth and abundant sporulation in rice grains. Isolates considered effective showed larger number and higher length of lettuce seedlings, compared to the control with the pathogen.

The first experiment was carried out in seedling trays containing 200 cells, divided into four quadrants with 36 cells each. The cells were filled with $15.3 \mathrm{~cm}^{3}$ of a commercial substrate Plantmax (Eucatex ${ }^{\mathrm{TM}}$ ) formulated with pine bark, vermiculite and turf and sown with two seeds of lettuce cultivar Tainá. The trays were moistened, covered with a plastic film and kept in the dark for three days until germination; then, they were transferred to a greenhouse. After two weeks, two baits colonized with $S$. minor or S. sclerotiorum (prepared as previously described) were placed on the surface of each cell, close to the seedling, and covered with $5 \mathrm{~mL}$ per cell of a mixture containing the isolates of Trichoderma ( $1 \mathrm{~g}$ of each formulated isolate per liter of substrate). Seven days later, a second application was made with $200 \mathrm{~mL}$ of a suspension of each isolate evenly distributed in each quadrant of the trays (36 cells). The suspensions contained $10^{6}$ conidia $\mathrm{mL}^{-1}$ of each Trichoderma isolate. The second experiment was conducted with the same isolates but in seedling trays containing 128 cells, which were filled with $112 \mathrm{~cm}^{3}$ of the same commercial substrate of the previous experiment, Plantmax (Eucatex ${ }^{\mathrm{TM}}$ ). The same methodology was used for this experiment, with the exception that quadrants had 21 cells each and, since the cells were larger, each seedling received four baits colonized with each pathogen.

\section{Identification of Trichoderma isolates}

All four Trichoderma isolates tested in the previous step were identified at species level by sequencing the ITS (internal transcribed spacer) region and elongation factor- $1 \alpha$ gene (EF). Before extraction of the genomic DNA, single spore cultures of each isolate were grown in Petri dishes containing PDA medium and maintained for 7 days at $25^{\circ} \mathrm{C}$. DNA was extracted from mycelia ground with a plastic pestle under liquid nitrogen, using the Ultra Clean Plant DNA extraction Kit (Mobio Inc.), according to the manufacturer's instructions. Amplification of the ITS region was performed with primers ITS1 and ITS4 (26) and that of the EF gene with primers tef71f and tef $997 \mathrm{r}$ (21). Amplified products were sequenced by adopting the chain termination method using BigDye 3.1 and an automated sequencer 3500xL Genetic Analyzer (Applied Biosystems). Sequences were deposited in the GenBank under the accession numbers KJ646883 through KJ646886 for ITS region, and KP262478 through KP262481 for EF gene. Species identification was performed by comparing the ITS and EF sequences of isolates with the sequences present in the ISTH (International Subcomission on Trichoderma and Hypocrea Taxonomy) database, using the program TrichOKEY (5), and with the sequences of authentic specimens deposited in the GenBank using the program Blastn.

\section{Experimental design and statistical analysis}

The experiments carried out in the laboratory to evaluate pathogen control with Trichoderma isolates were performed in a completely randomized design with four replicates per treatment, each replicate represented by a Petri dish containing 10 lettuce seedlings. ANOVA of the data was performed and means of the length of lettuce seedlings were compared according to Tukey's test at $5 \%$ probability.

The two greenhouse experiments were performed in a completely randomized design with four replicates, and each replicate was represented by 36 or 21 cells for the first and second experiments, respectively. Control treatments with only $S$. minor or $S$. sclerotiorum were kept for each experiment. ANOVA of the number of seedlings and the dry weight of seedlings was performed and means were compared according to Tukey's test at $5 \%$ probability.

\section{RESULTS}

In the experiments carried out in the laboratory, all Trichoderma treatments showed a larger number of viable lettuce seedlings than that of $S$. minor or S. sclerotiorum alone controls. Twenty-eight isolates of Trichoderma spp. ( $90.3 \%$ of the isolates) showed larger lettuce seedlings, compared to the control S. minor alone. Twenty-two isolates (IBLF880, IBLF 881, IBLF 882, IBLF 883, IBLF 888, IBLF 889 and IBLF 891 in the first experiment, IBLF 901, IBLF 903, IBLF 904 and IBLF 906 in the second, IBLF 896, IBLF 897, IBLF 908, IBLF 910, IBLF 912 and IBLF 914 in the third, and IBLF 919, IBLF 923, IBLF 924, IBLF 926 and IBLF 931 in the fourth experiment) also showed larger lettuce seedlings than those of the control S. sclerotiorum alone (Table 1).

The four isolates used in the experiments carried out under greenhouse conditions were identified as T. asperellum (IBLF 897, IBLF 905 and IBLF 914) and T. asperelloides (IBLF 908) based on the comparison of ITS and EF sequences. ITS and EF sequences of T. asperellum isolates were identical to each other and also to the sequences of isolate GJS 04-15 (ITS - GU198311, EF - GU198290). ITS and EF sequences of $T$. asperelloides isolate were identical to the sequences of isolate GJS 99-6 (ITS - DQ315464, EF - GU198240).

In both experiments carried out in the greenhouse, all treatments showed a larger number (Figures 1A, 1C) and larger dry mass of lettuce plants, compared to the alone control $S$. minor, while Trichodermatreated lettuce plants produced dry masses similar to those of the control without the pathogen (Figures 1B, 1D). For S. sclerotiorum, similar results were observed in both experiments - all treatments showed a larger number and larger dry mass of lettuce plants than those of the control with the pathogen, but $S$. sclerotiorum was more aggressive than $S$. minor, and the seedlings of Trichoderma treatments exhibited smaller dry masses, compared to the control without the pathogen (Figures 1A, 1B, 1C, 1D). 
Table 1. Experiments conducted in vitro for the selection of isolates of Trichoderma spp. antagonistic to Sclerotinia minor and S. sclerotiorum, causal agents of lettuce drop.

\begin{tabular}{|c|c|c|c|c|c|c|}
\hline \multirow[b]{2}{*}{ Experiments } & \multirow[b]{2}{*}{$\begin{array}{c}\text { Number of } \\
\text { isolates } \\
\text { tested }\end{array}$} & \multicolumn{2}{|l|}{ S.minor } & \multirow[b]{2}{*}{$\begin{array}{c}\text { Number of } \\
\text { isolates } \\
\text { tested }\end{array}$} & \multicolumn{2}{|c|}{ S.sclerotiorum } \\
\hline & & $\begin{array}{l}\text { IBLF number of effective isolates of } \\
\text { Trichoderma } \text { spp. }{ }^{1}\end{array}$ & $\begin{array}{l}\text { Percentage of } \\
\text { effective isolates of } \\
\text { Trichoderma } \text { spp. }\end{array}$ & & $\begin{array}{c}\text { IBLF number of effective } \\
\text { isolates of Trichoderma } \\
\text { spp. }{ }^{1}\end{array}$ & $\begin{array}{c}\text { Percentage of } \\
\text { effective isolates of } \\
\text { Trichoderma spp. }\end{array}$ \\
\hline Experiment 1 & 10 & $\begin{array}{c}880,881,882,883,885,886,887 \\
888,889 \text { and } 891\end{array}$ & 100.0 & 10 & $\begin{array}{c}880,881,882,883,888 \\
889 \text { and } 891\end{array}$ & 70.0 \\
\hline Experiment 2 & 10 & $894,895,900,901,903,904$ and 906 & 70.0 & 10 & 901, 903, 904 and 906 & 40.0 \\
\hline Experiment 4 & 5 & $919,923,924,926$ and 931 & 100.0 & 5 & $\begin{array}{c}919,923,924,926 \text { and } \\
931\end{array}$ & 100.0 \\
\hline
\end{tabular}

${ }^{1}$ Isolates considered effective improved the size of the radicle and the hypocotyl of lettuce seedlings and the number of surviving lettuce seedlings.
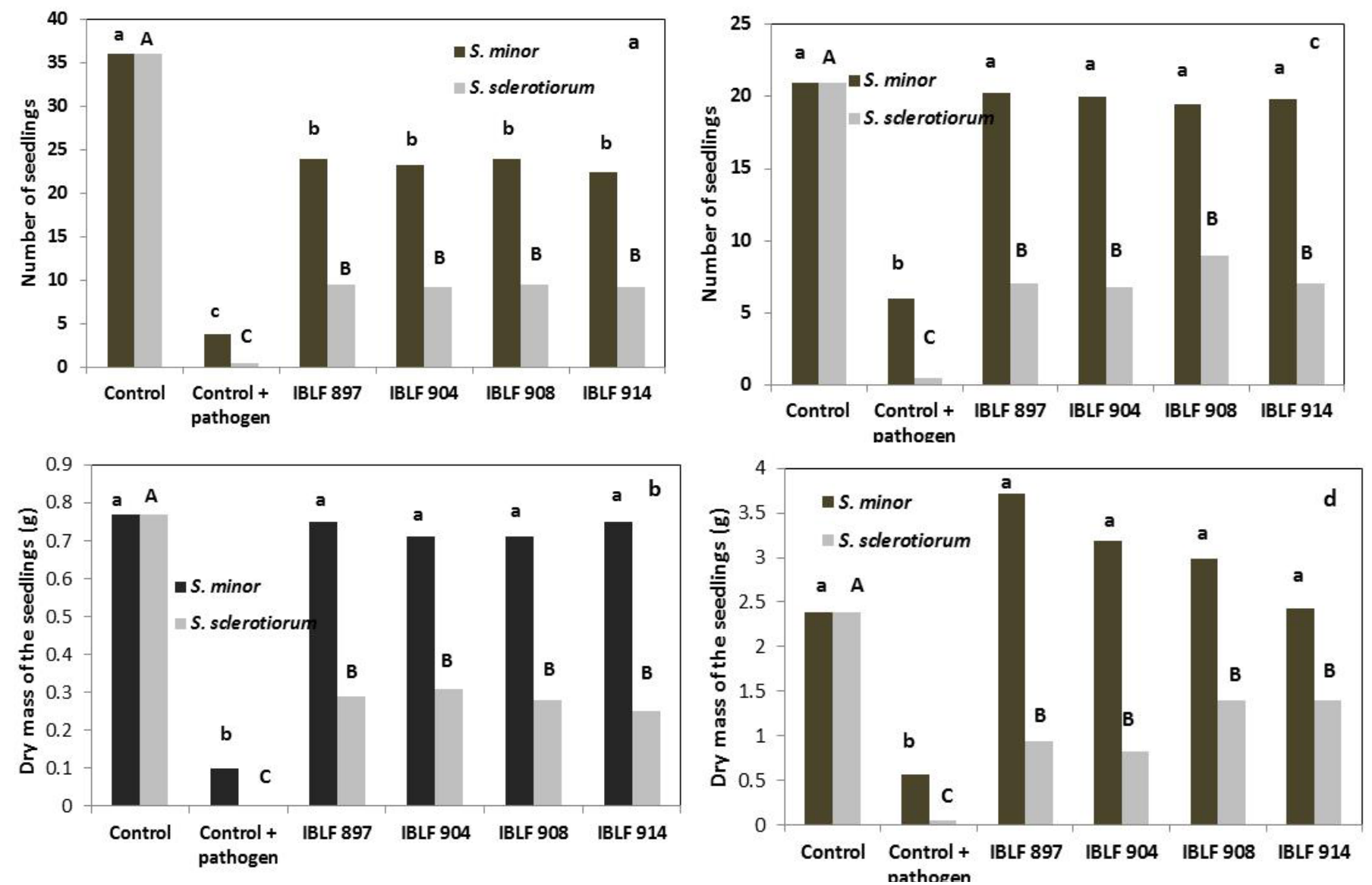

Figure 1. Number of surviving lettuce seedlings (A, C) and dry mass of lettuce seedlings (B, D) in the first (A, B) and second (C, D) experiments carried out to select isolates of T. asperellum (IBLF 897, IBLF 904 and IBLF 914) and T asperelloides (IBLF 908) antagonistic to S. minor and $S$. sclerotiorum, causal agents of lettuce drop.

\section{DISCUSSION}

In this study, Trichoderma isolates antagonistic to $S$. minor and $S$. sclerotiorum were selected because lettuce drop is an important disease that has not been sufficiently studied in Brazil, and most studies of this pathosystem employ commercial products containing Trichoderma or Coniothyrium, usually formulated with strains that were not selected for this purpose. Lettuce producers are motivated to adopt biological control due to insufficient control of this and other diseases in their crops and because they are concerned about pesticide residues. Lettuce is consumed fresh and has a very short cycle, 30 to 45 days after transplanting of seedlings, which enhances the probability of their contamination with pesticides. For example, in 2011-2012, $41 \%$ of the lettuce samples analyzed to detect pesticides in Brazil were contaminated with pesticides not registered for the culture (2).

In this study, Trichoderma was the microorganism most frequently 
isolated from baits containing mycelia of S. minor and S. sclerotiorum and was the main antagonist obtained from sclerotia in other studies $(6$, 10). Trichoderma is a frequent soil fungi that is present in root systems and exhibits an important capacity for mycoparasitism against several plant pathogenic fungi (25).

The method of baits employed in this study to obtain Trichoderma isolates was effective especially because a high percentage of the isolates $(73.3 \%)$ showed ability to mycoparasitize both pathogens. This methodology was already used in previous studies for other pathogens (16), but sclerotia were also used as baits to obtain Trichoderma isolates antagonistic to $S$. sclerotiorum $(6,10)$. In this study, the ability to mycoparasitize mycelia of $S$. minor and $S$. sclerotiorum was privileged in the selection process because, in addition to antibiosis, this is the main biocontrol strategy used by Trichoderma species to promote the biocontrol of plant pathogens (25), especially those producing sclerotia (1).

In the in vitro studies, a method that included the host and pathogens on plates containing a nutrient-poor medium (water-agar) was employed. This method privileges the mycoparasitic activity of the biocontrol agent and was adapted from a previous study with Pythium spp. in lettuce cultivars (24). Although it differs from those used by other authors, such as the modified cellophane method, antibiosis or direct confrontation $(6,7,13,16)$, it was already employed for biological control studies. Bernardes et al. (3) evaluated the antagonism of rhizobacteria to $P$. aphanidermatum in lettuce seedlings, and Patekosky $\&$ Pires-Zotarelli (15) used this method to assess the biological control of $P$. aphanidermatum with a commercially formulated Trichoderma. Since the obtained Trichoderma isolates were effective for both pathogens in the greenhouse experiments, this method could be used in further studies.

In the greenhouse experiments of this study, the biocontrol of S. sclerotiorum was achieved with the selected Trichoderma isolates, and similar results were observed by other authors $(7,12$, 20). Mycoparasitism is probably the main mechanism employed by antagonists of sclerotia producing fungi (25). Abdullah et al. (1) found that an isolate of T. harzianum penetrated the mycelia of S. sclerotiorum and was able to degrade the hyphae and sclerotia and to inhibit the formation of new sclerotia. Mycoparasitism is accomplished through the recognition of the host, followed by the attack, penetration and killing. It is well known that Trichoderma species produce cell-wall degrading enzymes, as well as several antibiotics which are used during the degradation of the host hypha (25).

In the second experiment carried out in the greenhouse, the lettuce seedlings treated with Trichoderma and inoculated with $S$. minor showed larger dry mass than that of the control without the pathogen, although this difference was not statistically significant. This is a quite common phenomenon in several experiments. It is well known that some Trichoderma strains can colonize root surfaces and promote changes in plant metabolism and some strains can promote plant growth and increase nutrient availability (25). This phenomenon may be related to metabolites released by Trichoderma isolates that enhance the efficiency of nutrient transport from the roots, especially nitrogen, which stimulates plant growth (25).

The development of a feasible and reproducible method to select isolates in experiments carried out in the greenhouse in this study was only possible after several previous experiments had been performed. The use of baits (wheat grains colonized with each pathogen) permitted the application of exactly the same amount of viable inoculum to each lettuce seedling, and this method could be used in further studies with this same pathosystem. In the greenhouse experiments, in which the amount of inoculum was very high, Trichoderma isolates were effective for the control of $S$. minor and partially effective for the control of $S$. sclerotiorum. Similarly, in New Zealand, Jones and Stewart (11) showed that Trichoderma isolates promoted partial $S$. minor control but at levels similar to those obtained with the fungicide Benomyl. Rabeendran et al. (20) observed a significant reduction in lettuce drop by using isolates of $T$. virens and T. hamatum in a field infested with $S$. minor.

In this study, four Trichoderma isolates were obtained with potential to be used for controlling lettuce drop in Brazil.

\section{REFERENCES}

1. Abdullah, M.T.; Ali, N.Y.; Suleman, P. Biological control of Sclerotinia sclerotiorum (Lib.) de Bary with Trichoderma. Crop Protection, Guildford, v.27, p.1354-1359, 2007.

2. ANVISA. Programa de análise de resíduos de agrotóxicos em alimentos (PARA) -Relatório 2011-2012. Available at: http://portal. anvisa.gov.br/wps/wcm/connect/d480f50041ebb7a09db8bd3e2b7e7e4d/ Relat\%C3\%B3rio\%2BPARA\%2B2011-12\%2B-\%2B30_10_13_1. pdf?MOD=AJPERES $>$. Accessed on 6 Jan. 2014.

3. Bernardes, F.S.; Patricio, F.R.A.; Santos, A.S.; Freitas, S.S.. Indução de resistência sistêmica por rizobactérias em cultivos hidropônicos. Summa Phytopathologica, Botucatu, v.36, n.2, p.115-121, 2010.

4. Chitrampalam, P.; Figuli, P.J.; Matheron, M.E. Biocontrol of lettuce drop caused by Sclerotinia sclerotiorum and S. minor in desert agroecosystems. Plant Disease, St. Paul, v.92, n.12, p.1625-1634, 2008.

5. Druzhinina, I.; Kopchinskiy, A.; Komon, M.; Bissett, J.; Szakács, G.; Kubicek, C.P. An oligonucoeotide barcode for species identification in Trichoderma and Hypocrea. Fungal Genetics and Biology, Madison, v.42,p.813-828, 2005

6. Ethur, L.Z.; Muniz, M.; Silva, A.C.; Stefanelo, D.R.; Rocha, E.K. Fungos antagonistas a Sclerotinia sclerotiorum em pepineiro cultivado em estufa. Fitopatologia Brasileira, Viçosa, v.30, n.2, p.127-133, 2005.

7. Ethur, L.Z.; Cembranel, C. Z.; Silva, A.C.F. Seleção de Trichoderma spp. visando ao controle de Sclerotinia sclerotiorum, in vitro. Ciência Rural, Santa Maria, v.31, n.5, p.885-887, 2001.

8. Ghini, R.; Kimati, H. Método de iscas para obtenção de isolados de Trichoderma antagônicos a Botrytis cinerea. Jaguariúna: EMBRAPA-CNPDA, 1989. (EMBRAPA-CNPDA. Boletim de Pesquisa, 3).13p.

9. Hao, J.J.; Subbarao, K. V. Comparative analyses of lettuce drop epidemics caused by Sclerotinia minor and S. sclerotiorum. Plant Disease,St. Paul, v.89, n.7, p.717-725, 2005.

10. Ibarra-Medina, V.A.; Ferrera-Cerrato, R.; Alarcón, A.; Lara-Hernández, M. E.; Valdez-Carrasco, J.M. Aislamiento y selección de cepas de Trichoderma antagonistas a Sclerotinia sclerotiorum y Sclerotinia minor. Revista Mexicana de Micologia, Montecillo, v.31, p.53-63, 2010.

11. Jones, E.E.; Stewart, A. Biological control of Sclerotinia minor in lettuce using Trichoderma species. New Zealand Plant Protection Conference, Auckland, p.154-158, 1997.

12. Knudsen, G.R.; Eschen, D. J.; Dandurand, L. M.; Wang, Z.G. Method to enhance growth and sporulation of peletized biocontrol fungi. Applied and Environmental Microbiology, Washington D.C., v.57, n.10, p.28642867, 1991.

13. Lucon, C.M.M.; Koike, C.M.; Ishikawa, A.I.; Patrício, F.R.A.; Harakava, R. Bioprospecção de isolados de Trichoderma spp. para o controle de Rhizoctonia solani na produção de mudas de pepino. Pesquisa Agropecuária Brasileira, Brasília, v.44, n.3, p.225-232, 2009.

14. Matheron, M.E.; Porchas, M. Activity of boscalid, fenhexamid, fluazinam, fludioxonil, and vinclozolin on growth of Sclerotinia minor and S. sclerotiorum and development of lettuce drop. Plant Disease, St. Paul, v.88, p.665-668, 2004.

15. Patekosky, K.S.; Pires-Zotarelli, C.L.A. Patogenicidade de Pythim aphanidermatum a alface cultivada em hidroponia e seu biocontrole com Trichoderma. Pesquisa Agropecuária Brasileira, Brasília, v. 45, n.8, p.805-810, 2010

16. Patricio, F.R.A.; Kimati, H.; Barros, B.C. Seleção de isolados de Trichoderma 
spp. antagônicos a Pythium aphanidermatum e Rhizoctonia solani. Summa Phytopathologica, Botucatu, v.27, p.223-229, 2001.

17. Patterson, C.L.; Grogan, R.G. Differences in epidemiology and control of lettuce drop caused by Sclerotinia minor and S. sclerotiorum. Plant Disease, St. Paul, v.69, p.766-770, 1985.

18. Paula Júnior, T.J.; Vieira, R.F.; Rocha, P.R.R.; Bernardes, A.; Costa, E.L.; Carneiro, J.E.S.; Vale, F.X.R.; Zambolim, L. White mold intensity on common bean in response to plant density, irrigation frequency, grass mulching, Trichoderma spp., and fungicide. Summa Phytopathologica, Botucatu, v.35, p.44-48, 2009.

19. Pavan, M.A.; Krause-Sakate, R.; Kurozawa, C. Doenças da alface. In: Kimati, H.; Amorim, L.; Rezende, J.A.M.;Bergamin Filho, A.; Camargo, L.E.A. (Eds.). Manual de Fitopatologia: doenças das plantas cultivadas. São Paulo: Editora Agronômica Ceres, 2005. p.27-33.

20. Rabeendran, N.; Jones, E.E.; Moot, D.J.; Stewart, A. Biocontrol of Sclerotinia lettuce drop by Coniothyrium minitans and Trichoderma hamatum. Biological Control, Lexington, v.39, p.352-362, 2006.

21. Shoukouhi, P.; Bissett, J. Preferred primers for sequencing the 5 ' end of the translation elongation factor 1-alpha gene (eEF1a1). Available at: http:// www.isth.info/methods. Accessed on: 10 Dec. 2014.

22. Subbarao, K.V. Progress toward integrated management of lettuce drop. Plant Disease, St. Paul, v.82, n.10, p.1068-1078, 1998.

23. Subbarao, K. V. Lettuce drop. In: Davis, R.; Subbarao; K.V.; Raid, R. N.; Kurtz, E.A. (Eds.) Compendium of lettuce diseases. St. Paul: American Phytopathological Society, 1997. p.19-21.

24. Teixeira, L.D.D.; Zotarelli, C.L.A.P.; Kimati, H. Efeito da temperatura no crescimento micelial e patogenicidade de Pythium spp. que ocorrem em alface hidropônica. Summa Phytopathologica, Botucatu, v.32, n.3, p.221-226, 2006.

25. Vinale, F.; Sivasithamparam, K.; Ghisalberti, E. L.; Marra, R.; Woo, S. L.; Lorito, M. Trichoderma-plant-pathogen interactions. Soil Biology \& Biochemistry, Elmsford, v.40, p.1-10, 2008.

26. White, T.J.; Bruns, T.; Lee, S.; Taylor, J.W. Amplification and direct sequencing of fungal ribosomal RNA genes for phylogenetics. In: Innis, M.A.; Gelfand, D. H.; Sninsky, J.J.; White, T.J. (Eds) PCR Protocols: a guide to methods and applications. Academic Press: New York, 1990. p.315-322. 